\title{
Police Performance as Symbolic Politics? Public Recognition and the Value of Awards
}

\author{
Peter Stanley Federman
}

What constitutes "good" performance in a law enforcement agency, who decides, and how does public recognition of that performance change how an agency performs? This study uses a quasiexperimental design and propensity-score matching model to assess the impact of a law enforcement agency's status as a finalist for the annual Cisco/International Chiefs of Police Association (IACP) Community Policing Award on performance in future years, as measured by crime clearance rates. It is found that after comparing the treated group (finalist agencies) with the untreated group (non-finalist nearest-neighbor agencies), there is no meaningful difference in crime clearance rates. This unexpected finding establishes that the public recognition of finalist status by the Department of Justice, which promotes finalist agencies as exemplars of best practices in community policing, does not impact the subsequent performance of those agencies. Additionally, the results of the model suggest that the impact of symbolic politics and social construction on the award finalist selection process and the choice by DOJ to promote the practices of those agencies should be explored. Questions are also raised as to the utility of crime clearance rates as a performance measure, and future avenues for research in each area are proposed.

Keywords: performance, public administration, policing

This is the author's manuscript of the article published in final edited form as:

Federman, P. S. (2020). Police Performance As Symbolic Politics? Public Recognition and the Value of Awards. Public Performance \& Management Review, 43(2), 363-387. https://doi.org/10.1080/15309576.2019.1676275 


\section{Introduction: Performance and Awards in the Public Sector}

Public administration scholarship has developed frameworks and theories to better measure the performance of public agencies (Bozeman \& Moulton, 2011; Moynihan, 2008, 2015; O'Toole \& Meier, 2014), as well as to assess the factors that contribute to better performance by those organizations (Hvidman \& Andersen, 2014; Langbein \& Stazyk, 2013; Span, Luijkx, Schols, \& Schalk, 2011). This scholarship includes work on law enforcement agencies and indicates that such measurement is possible, as well as valuable when assessing whether law enforcement agencies are meeting their constituents needs (Ammons \& Madej, 2018; Bromberg, Charbonneau, \& Smith, 2018; Gorby, 2013; Pasha, 2018; Shane, 2010). However, a critical question remains unanswered: how is "good" performance among law enforcement agencies recognized publicly, and what is the impact of that recognition?

Organizational or individual awards and recognition are often considered under the purview of labor economics and related fields. The studies that have been conducted in those disciples often use the individual as the unit of analysis. Such studies have proven inconclusive about how and where awards matter, whether public or private recognition leads to better worker performance, or if high performing individuals lead to higher performing organizations. While it is generally agreed upon that the giving of awards improves the performance of individuals, the same may or may not be true for organizations, particularly those in the public sector (Gerhards \& Siemer, 2014; Kosfeld \& Neckermann, 2011). Law enforcement organizations, many of which measure performance closely and narrowly, are an ideal group to utilize in conducting a study within the academic and theoretical bounds of public administration that looks at the impact of awards on performance. 
Recent relevant research on performance among law enforcement organizations includes assessing how representative bureaucracy impacts the implementation of policy, the use of binary comparisons to assess trends in performance, the impact of organizational commitment and work engagement, and citizen participation in performance measurement (Chand, 2019; Guilfoyle, 2015; Ho, 2015; J. Nicholson-Crotty, Nicholson-Crotty, \& Li, 2018; van Gelderen \& Bik, 2016). These are merely a few of the topics discussed within the literature, and it is fair to state that the theoretical landscape of performance measurement among law enforcement agencies is not only broad, but also ripe for expansion. This study seeks to assess the impact of public recognition of a law enforcement agency's nomination and selection as a finalist for a prominent award, which is said to be based in part on performance, on how that agency performs after being publicly recognized.

There is little consensus on the causal relationship between public sector awards and performance, though award programs continue to proliferate in the public sector and multiple scholars have called for the study of their relationships to effectiveness and performance (Borins, 2000; Entwistle \& Downe, 2005; Frey, 2007; Rosenblatt, 2011). According to Hartley and Downe (2007), to ensure that awards are given to the most effective organizations and programs, the award-giving process (or scheme) must be structured in such a way as to encourage large numbers of representative applicants, and multiple stakeholders should observe the application and selection process. Further, once awards are given, the relative improvement of organizations should be measured post-hoc, and organizers of award processes should self-assess and updated their processes frequently to ensure the continued relevance of the award (Hartley \& Downe, 2007; Löffler, 2001). 
Finally, although there is research in public administration that has addressed organizational performance and awards outside of a direct causal relationship, this has primarily focused on the factors that lead to improved performance, including leadership, strategic planning, benchmarking, and process management among other factors (Kapucu, Volkov, \& Wang, 2011; Kouzmin, Löffler, Klages, \& Korac-Kakabadse, 1999; Wang, 2002). Beyond this, there are also a number of other far-ranging literatures related to performance in the public sector, including the links between performance and creativity, democratic accountability, and gender, among other factors (Meier, Mastracci, \& Wilson, 2006; Ospina, Cunill Grau, \& Zaltsman, 2004; Rangarajan, 2008). However, to this point, public administration has been lacking a thoroughly researched and delimited empirical literature that considers the specific consequences of an organization receiving an award, and the connection to future performance.

Following, a brief literature review provides a working definition of community policing, as well as background on the International Association of Chiefs of Police (IACP) and the Office of Community Oriented Policing in the Department of Justice (COPS), providing further context for the research question. Two theoretical frames that may prove useful for understanding the results of the model, symbolic politics and social construction, are also reviewed. Next, an examination of the methodology outlines the propensity-score matching model, explaining the utility of nearest-neighbor matching and the quasi-experimental nature of the design. The findings of the model are then presented and followed by a discussion that explores why performance as measured by clearance rates did not rise after the public recognition of awardfinalist agencies. Finally, the conclusion offers several potential avenues for future research, including assessing the utility of crime clearance rates as a performance measure, exploring the possibility of social construction as a driving force behind law enforcement agency policy, and 
assessing the role symbolic politics may play in the award nomination and finalist selection process.

\section{Community Policing: The Roles of the IACP and COPS}

What constitutes effective and fair policing in the United States and the promotion of those policies falls within the purview of the Department of Justice. While the Department of Justice does compile internal reports and promotes best practices developed from within, it also turns to outside organizations, including interest groups and professional organizations, to find and promote best practices. One such group is the International Association of Chiefs of Police (IACP), a well-known and established professional organization that boasts the largest membership of any organization of police executives, exceeding 20,000 in over 100 different countries (Fields, 2007).

A primary function of the Department of Justice's Office of Community Oriented Policing Services (COPS) is to provide grant funding, including over $\$ 12.4$ billion in grants and aid since 1995, to law enforcement agencies across the country to promote the development of community-oriented policing programs and to support existing community policing programs (Fields, 2007). Research on the effectiveness of grants from COPS is mixed, though evidence suggests they have been effective in lowering crime rates in many municipalities (Zhao, Scheider, \& Thurman, 2002). As an organization tasked with such a significant amount of funding to distribute, it is worth noting that COPS has used the IACP Community Policing Award as a direct proxy for Department of Justice-endorsed best practices in community policing for decades. In 2007, COPS published a report titled Award-Winning Community Policing Strategies (1996-2006), that cited finalist status for the IACP Community Policing 
Award as their primary marker for determining the effectiveness of community policing programs. A letter contained in the report from Carl Peed, Director of COPS, reads in part:

This report offers a brief description of approaches that have been successfully developed and implemented at the local level to reduce crime and disorder. We are confident that many of the strategic principles documented in the report can be modified as needed and adopted by other law enforcement agencies in support of their efforts to develop and implement community policing programs that address challenges they may be confronting. Moreover, the jurisdictions that implemented the approaches detailed in this report should be commended for their innovativeness and commitment to community policing.... Congratulations to the Community Policing Award winners and finalists, and thank you again for your commitment to fighting crime and disorder through effective community policing approaches (Fields, 2007, p. iv).

The report makes clear that the Department of Justice is confident that finalist status for the IACP Community Policing Award is an indicator of best practices in community policing. According to the award's website (IACP, 2018a), departments can self-nominate for this award or be nominated by outside entities, with hundreds of nominations submitted each year. The process of choosing the finalists is opaque and conducted solely by the members of the IACP Community Policing Committee, who are chiefs, superintendents, or command-level police officers in public law enforcement agencies (Fields, 2007; IACP, 2018b). Therefore, it is difficult to predict what leads to a department being nominated, but it is possible to measure how community policing programs fare after being selected as finalists. 
In order to substantively engage in such an analysis, it is important to first understand the tenets of community policing. According to numerous scholars, community policing is broadly defined as the engagement between police leadership, community leadership, and citizens to prevent crime (Chappell, MacDonald, \& Manz, 2006; Engel \& Worden, 2003; Mastrofski, Snipes, Parks, \& Maxwell, 2000; B. Taylor, Koper, \& Woods, 2011). The idea of community policing dates back to the 1980 s, and the efforts of reformers to engage police with communities in new and innovate ways. While community policing originated in big cities such as New York and Los Angeles, it has spread to urban, suburban, and rural communities since its inception (Weisburd \& Braga, 2006; Zimring, 2011).

Community policing has also expanded to include collaborative service provision and how such shared service agreements promote community-focused policing practices (Carrizales, Melitski, \& Schwester, 2010; Choi \& Choi, 2012). Community policing is not without its critics, as more recent work has shown it is often most effective in places where it may not be needed, including in urban areas that already have lower crime rates (McCandless, 2018; Rukus, Warner, \& Zhang, 2018). Scholars have also suggested that community policing serves primarily as a promotional tool for police departments, and that actual interactions with citizens are infrequent and dismissive (Liederbach, Fritsch, Carter, \& Bannister, 2008; Roussell \& Gascon, 2014).

Despite this criticism, community policing has become an institutionalized best practice, defined by several foundational elements. These elements, as characterized by Greene and Mastrofski (1988) are laid out below:

\section{[Table 1 here]}




\section{Measuring Performance in Community Policing}

Community policing has been studied extensively and across numerous types of departments, with performance outcomes measured in the traditional metrics of arrests, crime rates, and clearance rates, but also utilizing surveys to understand how citizens and officers perceive of the success of a program (Brewster, Stoloff, \& Sanders, 2005; Ostrom \& Whitaker, 1974; Willis, Mastrofski, \& Kochel, 2010). However, outside of those specific outcomes, others have pointed to the ability of community policing to fundamentally shift the role of police, from simple crime prevention to providing emergency services, reducing fear, and mobilizing communities (Moore, 1994). It is reasonable to assume that community policing is also intended to promote the reporting of crimes, as police build up trust and rapport with the communities they serve, and as later research has made abundantly clear (Friedmann, 1992; Skogan, 2004; Wilson, 2006). Solving crimes is made easier with more frequent reporting of crimes and witnesses willing to testify to a crime being committed. Clearly, effective community policing, with its intentions of developing these critical partnerships, might also be measured not only by crimes committed, but by crimes solved, particularly over an extended period of time.

The most often used and widely available metric to determine this is crime clearance rates, the ratio of crimes charged (or "solved") to crimes recorded. This measure has been utilized in performance management work on community policing, based on theoretical understandings of the goal of community policing programs, including those understandings and outcomes proposed by Friedmann (1992); Moore (1994); Skogan (2004) and Wilson (2006). While measuring the performance of community policing programs is difficult, particularly if success is measured by preventing crime as well as solving it, crime clearance rates are one of the factors that can and should be utilized as a measure of performance (Skolnick \& Bayley, 
1988). While the measure is imperfect, this study will utilize is based on the available evidence that it is, at the very least, a meaningful indicator of some elements of performance.

Crime clearance rates have been seen by some scholars as a controversial measure of performance, and there are studies that have shown no relationship or a negative relationship between clearance rates and performance indicators, citizen satisfaction and other normatively positive outcomes for police departments, suggesting that crime clearance rates may not be a useful measurement of police performance (Cook, 1979; Nagin, Solow, \& Lum, 2015; Pogarsky \& Loughran, 2016; Swindell \& Kelly, 2000). Beyond this, there are also concerns that crime clearance rates measure effectiveness without giving account to democratic values, such as due process or equity (Charbonneau \& Riccucci, 2008; McCandless, 2018). Since this disagreement on the utility of clearance rates as a performance measurement remains a salient debate, a secondary goal of this study is to reassess the value of those rates as a meaningful representation of performance in community policing programs.

Despite these criticisms, there are also scholars including Roberts (2008), Skogan (2004), and Litwin (2004) who suggest that crime clearance rates may increase under a well-performing community policing regime. While this relationship has yet to be fully explored, this study contributes to furthering that discussion by providing evidence of the impact public recognition of award finalist status has on crime clearance rates. If award-finalist programs have built up relationships over time with community leaders, developed trust between officers and the communities they serve, and created an environment in which citizens are both comfortable and satisfied with their police department, crime clearance rates, according to this group of scholars, should rise among those award-finalist programs compared to other similar departments without award-finalist programs, particularly considering the temporal element of the data. 
Therefore, if crime clearance rates are a useful measurement of performance, the following question arises: Are crime clearance rates in police departments publicly recognized as finalists for the IACP Award higher in the years following that recognition as compared to departments serving similar populations that were not selected for the award?

\section{Social Construction and Symbolic Politics}

Community policing falls into the broad category of policing interventions, specific methods of policing utilized in a particular place or during a particular time and thereby measurable against the control group of a similar place or time lacking that intervention. Excellent work has been done on measuring these interventions, and those authors should be applauded for advancing the field of police performance measurement through quasiexperimental and experimental designs and analyses (Braga, 2005; Braga \& Bond, 2008; Weisburd \& Braga, 2006). However, this research considers the impact of public recognition of an intervention, and not of the intervention itself - an important distinction. Since this study considers how the public recognition of community policing programs and the subsequent promotion of those programs as best practices by the Department of Justice impacts performance, two specific theoretical frames will be considered when assessing how and why this recognition may make a impact, and what it means for the future measurement and study of police performance.

First, the theory of symbolic politics argues that, throughout the award finalist selection, recognition, and promotion process, both the IACP and the Department of Justice will promote themselves as organizations that recognize and highlight departments that serve particular populations and municipalities with particular characteristics in an attempt to improve their own 
public image and political standing. Most notably characterized by Edelman (1985), symbolic politics is best described as the notion that most large organizations with political interest engage in rhetoric and symbolism for political gains and to facilitate certain actions by citizens and voting groups. In particular, these organizations and the individuals within them take on social roles and representations of certain values, not always with bad intentions but potentially with negative consequences. Public officials engaged in symbolic politics tell their constituents or the recipients of their services what those citizens want to believe, constantly adapting and modifying their own views to match those of citizens (Edelman, 1985; Scheingold, 1974). These symbolic politics may play out in any policy area or within any organization, and the conclusions drawn in this work make note of the potential for this dynamic to exist within the boundaries of the policy areas and law enforcement departments discussed herein.

The framework of symbolic politics has been used to understand the relationship between groups of people and a wide variety of policies, including policies concerning busing, language, and labor (Chun, 2011; Citrin, Reingold, Walters, \& Green, 1990; Sears, Hensler, \& Speer, 1979). Perhaps most relevant to this research, symbolic politics has also been used to critique the politics of reinventing government, most notably by Fox (1996), who posits that symbolic politics can help explain the fascination among public administrators and scholars with the reinvention of government as a postmodern exercise in branding as opposed to a commitment to meaningful reform. This idea, of a politics of symbolism to the detriment of improved performance, is central to the findings presented herein. If the conclusions demonstrated in this work are valid, then the possibility of a similar relationship cannot be wholly discounted without further research. 
Second, it is possible that departments are seen as worthy of promotion and as a good choice to be a finalist for this award based in part upon the "deservedness" of the populations they serve, as set forward in the literature on social constructions of those populations (Kreitzer \& Watts Smith, 2018; Schneider, Ingram, \& de Leon, 2014). While a comprehensive understanding of the factors leading to selection as finalists would require considerably more research into that practice and a willingness on the part of the IACP to disclose those processes, it possible that the social construction of the served populations of award-finalist departments may influence how performance changes post-award, in concurrence with the symbolic politics promoted by the awarding institutions.

When populations are socially constructed, the policies that serve them are often developed to serve certain groups and not others, and the specific impacts of those policies is intentionally asymmetrical, with certain groups receiving far more benefit. When considered in conjunction with the work on community policing and the evidence that it has been most effective in certain communities, there is a compelling case to be made that these phenomena may be linked. Public policy can also be framed by policy makers as the result of a "problem" caused by citizens, which assigns blame to certain groups and makes explicit the political messaging that certain groups are more deserving than others. As these narratives are created, those who receive the benefits and burdens of public policy reconstruct their own perceptions of citizenship, deservedness, and political power (Mettler \& Soss, 2004).

Social construction has been shown to be a contributing factor to the giving of public sector awards and public recognition (Gayles, 2007; Steinacker, 2006). Beyond this, social construction is also considered a contributing factor to how governments decide who receives the benefits of a policy and how that is perceived by mass publics, a relationship that echoes that of 
the awarder-awardee (Breznau, 2016; Mettler \& SoRelle, 2014; Schneider et al., 2014; Soss \& Schram, 2007). Therefore, it is reasonable to connect these ideas to the work presented here, as the social construction of law enforcement agencies by the IACP and the Department of Justice may have a meaningful role to play in understanding how and why departments perform better or worse after receiving an award, and what that means for the public recognition of a department for best practices in community policing.

Finally, street-level bureaucrats, such as police officers, are likely to socially construct their clients in both implicit and explicit ways. In their professional roles, they construct and act within both professional and personal identities. These identities in turn impact how they interact with the public and execute the functions of their position. Race, class and gender of the bureaucrats and the professional environment in which they serve are particularly salient variables, and it is worth nothing that these categories are relatively homogenous within police departments in particular (Oberfield, 2011; Prokos \& Padavic, 2002; Watkins-Hayes, 2009).

\section{Methodology}

To answer the question proposed here, the following model assesses award finalists in state of California, which had 11 departments named as finalists for the IACP Community Policing Award between 2000-2006, more than any other state in the country. Public law enforcement agencies in California are frequently utilized to infer conclusions about public administration in the United States, including in the areas of interlocal service cooperation, municipal contracting, and community policing (Nelligan \& Bourns, 2011; Roussell \& Gascon, 2014; Zeemering, 2018). This is in part due to the public availability of data from the state, 
including crime rates, population served, demographic data, and other information on all police departments in the state.

The publicly available dataset for this study was obtained from the California Department of Justice and spans the years 2007-2014. It contains annual data on crime and demographics for every law enforcement agency in California. The data was cleaned to ensure only municipal police departments were included. In this case, "municipal police department" is defined by a law enforcement agency that serves a specific municipality. Departments that serve exclusively colleges, transportation systems, hospitals, parks, school districts, or state agencies were excluded, as were sheriff's departments and state law enforcement agencies, thereby ensuring a relevant comparison between units. Within the category of municipal departments, the City of Los Angeles Police Department was removed, based upon its outlier status both as department serving the second-most populated city in the country and as having been a finalist three times for this award, the only multiple-time finalist in the study. This left 10 departments, those of Clayton, Fontana, Fremont, Irvine, Irwindale, Los Gatos, Pasadena, Pittsburg, Santa Rosa, and Suisun City, to be considered as the treated group in the analysis.

A dummy variable was created indicating whether or not a given agency had received award finalist status between 2000-2006, and each observation recorded for that agency was categorized as such. In total, the number of observations (one per year per municipal department, 2007-2014) resulted in $n=3,193$. While a single state is an imperfect indicator for how a particular policy might be implemented or measured nationally, the way that state policies are framed, communicated and implemented can be helpful in understanding national trends (Bailey \& Rom, 2004; Cann \& Wilhelm, 2011; Caughey \& Warshaw, 2016; Jeon \& Haider-Markel, 2001). 
It should be noted that this study utilizes data collected post-award (2007-2014) to determine the performance outcomes of the departments that received award finalist status between 2000-2006. While this means that the conclusions herein cannot be considered predictive, they do provide important context in determining the value of the award, the ways in which police department change or adapt based upon obtaining this Department of Justice seal of approval, how police officers might change their behavior or practices based upon that status, and, perhaps most importantly, determining whether or not these best practices being put forward by the Department of Justice reflect programs that have continued to achieve positive outcomes since receiving award finalist status.

To understand the relevant indicators of performance post-award, a propensity score match is conducted, controlling for the variables of interest indicated in the table below and their relationship to crime clearance rates. Propensity score matching, a methodology originating in and most often practiced in the health sciences, is an effective method to measure the impact of given treatment, in this case community policing, on a given subject, in this case the jurisdiction policed by the departments considered here. In particular, the propensity score model can accurately compare treated and untreated units in relevant pairs, which is useful when attempting to compare agencies in the most populated state in the United States. Without matching agencies for comparison, the results would be thrown off by comparing agencies whose size, demographics, socioeconomics, and other characteristics vastly differ from each other to the point of making a comparison invalid.

The variables below are selected based upon their usage as variables of interests in multiple studies by the authors in Table 1, as well as their use as standard variables in the fields of both criminal justice and public administration. The county variable clarifies the departments 
regionally and jurisdictionally, helping to ensure a consistent match among similar agencies. The various crime and arrested-related variables measure the specific type, level and manner of crimes and arrests each department deals with, which eliminates the inadvertent matching of agencies who are similar in population and demographics served but not in criminal behavior observed and available police resources. Finally, the racial indicator variables and population served variable help to define the agencies demographically based on the populations they serve, which is critical to matching accurately and to understanding how social construction and symbolic politics may contribute to the conclusions of this research.

\section{[Table 2 here]}

Propensity score matching was chosen as a methodology because of its unique ability to detect differences between treated and untreated groups. While a difference-in-differences estimator would be another possibility for analyzing this data, propensity score matching is helpful in eliminating extreme outliers, of which there are many within this dataset. While the method has been criticized for being susceptible to omissions within observations of the dependent variable (clearance rates), the benefit of matching like departments and avoiding the comparison of the San Diego or San Francisco police departments with small, rural California departments outweighs these concerns. By utilizing this method, there can be confidence that the broader question will be answered accurately and without the interference of extreme outliers, which for the purposes of this study is more important than exact clearance rates and p-values. Propensity score matching has also been shown to be an accurate measurement even among treatment groups with a small $n$ of treated units. Although it suffers from the same drawbacks as 
other quantitative methodologies when it comes to analyzing small $n$ data, it has also been shown to be relatively effective in mitigating some of those drawbacks, including when tested against difference-in-difference estimators (Austin, 2009a, 2009b; Hajage, Tubach, Steg, Bhatt, \& De Rycke, 2016; O’Neill, Kreif, Grieve, Sutton, \& Sekhon, 2016) ${ }^{1}$.

Propensity score matching compares how policy outcomes differ for units that received a particular treatment, and compare them to observationally similar units that did not (Heinrich, 2010). The propensity score matching model conducted here uses nearest-neighbor matching with replacement, which matches each treated unit with its five closest neighbors, according to their calculated propensity scores. Untreated units can be utilized as matches for multiple treated units, and the propensity score is based on similarities in reported observations for the given variables (Heinrich, 2010). The estimator for propensity scores, or the average treatment effect (ATE), is as follows:

$$
\widehat{A T E}=\frac{1}{N_{T}} \sum_{i \in I_{1} \cap S p}\left\{Y_{I i}-\sum_{i \in I_{0} \cap S p} \omega_{i j} Y_{0 j}\right\}
$$

where $N_{T}$ is the number of treated units, $I_{l}$ is the set of treated units, $I_{0}$ is the set of untreated units, $S p$ is the common support and $\omega i j$ is the weight allocated to a given single unit based on its propensity score (Heinrich, 2010).

\footnotetext{
${ }^{1}$ While a difference-in-difference estimator was considered as a methodological alternative, the functionality of that model relies on data that covers both pre- and post-treatment periods, and is intended to gauge the change over time of a given variable across a group of units See: Bertrand, Duflo, and Mullainathan (2004); Abadie (2005); Imbens and Wooldridge (2009). Since this research is intended to measure the relationship between an agency receiving a prestigious award and future performance as compared to similar agencies, and not on the performance of a given agency before and after receiving an award, a propensity score matching model was determined to be the best choice.
} 


\section{Results}

[Figure 1 here]

Figure 1 shows the density of the propensity scores for California departments before and after matching using a normal density function. Since the distribution between the treated and control groups is better correlated after matching, we can assume that propensity score matching will be a useful way to determine the value of the treatment (Heinrich, 2010). While the beforematching graph shows a clear gap between propensity scores, the after-matching graph shows a more correlated relationship between the treated (award-finalist) departments and their five closest neighbors based on the variables included in the propensity score matching models below. Such a relationship demonstrates that matching in this way should provide more accurate insight into how award-nominated departments perform compared to other similar departments.

\section{[Table 3 here]}

As per the table above, there is no significant difference between treated and untreated departments when it comes to violent crime clearance rates. While there is a significant difference at the .01 level between treated and untreated departments for property crime clearance rates, the sign of the coefficient is negative, indicating that departments with awardfinalist community policing programs have lower property crime clearance rates than their five nearest-neighbors according to the model. This would indicate that by this measure, award- 
nominated departments are not more successful in achieving a specific and measurable goal of community policing: solving crimes.

Finally, the low pseudo r-squared, 0.1428 , suggests that there is more than meets the eye when it comes how finalist status impacts performance post-hoc. If finalist status was a good indicator of improved performance, we would expect the pseudo r-squared to reflect a model that captured a larger percentage of the relevant factors contributing to that improved performance. However, the low result supports the conclusion that even in a robust model that considers the traditional characteristics and variables used to measure community policing effectiveness, the full story cannot be told through this data alone.

\section{Discussion and Conclusions}

The results of this study constitute an effort to contribute to the ongoing discussion about efficacy and effectiveness in policing interventions and their ability to reduce crime (Pasha, 2018; Pollack, 2017; Saunders, Robbins, \& Ober, 2017). The first and most important contribution to this literature reached herein is that, according to a propensity score model using crime clearance rates as an indicator of performance, there is no evidence to suggest that police departments who were finalists for the IACP Community Policing Award have better crime clearance rates in the years following their selection than similar departments who were not finalists. This result suggests that when the Department of Justice complies a report on best practices for community policing using prior award finalists, they are not conducting any investigation into the crime clearance rates of those departments in the years following being selected as a finalist; or, the Department of Justice does not consider crime clearance rates a meaningful statistic and utilizes another measurement to assess performance. This leads to an 
important question for scholars: if departments are not being put forward by the Department of Justice as examples of best practice based on their ability to raise crime clearance rates in their community, what metrics are being considered? It would appear from the COPS Office report (Fields, 2007) that the only consideration is whether or not a department was a finalist for the IACP Community Policing Award.

If not performance, then what might be driving the selection of these departments as examples of "best practices" in community policing? While it is possible that the factors that determine finalist status are solely based in the organizational characteristics of departments themselves, and therefore unrelated to the demographics and other contextual factors of the population served by the department, it seem unlikely that the particulars of the population served by the department would have no impact on whether or not they obtained award finalist status or on performance thereafter. Therefore, this result presents a number of questions about how departments are chosen as finalists, and if perhaps there are structural and systemic forces are involved.

While the Department of Justice continues to rubber-stamp the recommendations of the IACP with regards to community policing best practices, it should be of pressing concern to scholars of criminal justice policy and policing to consider whether or not this process is accurately capturing the success or failure of community policing programs. Particularly in the contemporary policing context, with trust in police at very low levels and evidence to suggest that police stereotype and over-police certain communities, it is of utmost importance that the policies that constitute best practices in community policing be reexamined to determine if they are in fact the best way to move policing in a progressive and citizen-focused direction (Harrits, 2018; Soss \& Weaver, 2017; R. B. Taylor \& Lawton, 2012). 
To better understand these results, the discussion of them must be situated within the broader conversation around the impact of social construction on criminal justice policy. Scholars are aware of the explanatory power that this theoretical frame can bring to criminal justice policy, demonstrating how inmates are social constructed in such a way as to limit their access to health care (J. Nicholson-Crotty \& Nicholson-Crotty, 2004), the impact of racial attitudes on prisoners reentry policy (Percival, 2009), how public opinion can help shape numerous types of punitive criminal laws and policies (Enns, 2014; S. Nicholson-Crotty, Peterson, \& Ramirez, 2009; Owens \& Smith, 2012), and perhaps most importantly, how the social construction of racial groups is a crucial factor in understanding how policy is designed and carried out in different ways for different populations (Cingranelli, 1981; Schneider et al., 2014; Sharp, 2014; Soss, Fording, \& Schram, 2011; Weaver \& Lerman, 2010).

Further, public interest groups such as the IACP have the ability to obtain power and influence in the policy formulation process, including those who are organized and funded by collaboration with other interest groups or by the nature of the group including large populations of engaged citizens (Campbell, 2003). However, this is rarely the case for prisoners, low-income citizens, minorities, or others who are likely to be policed or subject to the carceral face of the state (Soss \& Weaver, 2017). Governments are in control of who they deem legitimate citizens, and that is often mitigated or propagated by the socially constructed identities of a given population. This effect is magnified when it comes to minority communities, particularly lowincome or black communities (Baumgartner, De Boef, \& Boydstun, 2008; Soss, Fording, \& Schram, 2008).

The formulation and implementation of policy is crucial to defining citizenship, status and political engagement for individuals. When the design and implementation of a policy is 
such that it leaves citizens who engage with it feeling negatively about the government, that perception will carry over to how they conceive of themselves in relationship to the state. For example, recipients of food stamps are often treated differently from those receiving social security, resulting in vastly different perceptions of citizenship and substantially different characterizations of citizen's relationships to the state (Campbell, 2003; Mettler \& Soss, 2004). These same policies are formulated in such a way as to provide certain benefits to certain groups, while generating costs for others. This results in a policy whose impact recipients perceive in one way, and government officials and citizens who are not impacted by the policy perceive entirely differently (Jordan \& Matt, 2014; Mettler \& SoRelle, 2014; Soss, 1999).

If the social construction of populations is relevant to the lack of significant difference in crime clearance rates among finalist and non-finalist departments, it holds implications for the study of public management and performance management, particularly concerning law enforcement agencies. In particular, it suggests indicate that scholars must pay closer attention to contextual factors as suggested by Meier, Rutherford, and Avellaneda (2017), as well as to how policing is carried out in different social and institutional contexts (Leon-Moreta, 2018). Further, it will require scholars of public agency performance to closely reexamine how performance is conceptualized and measured to ensure that the social construction of populations is included in their analysis. To move the conversation around the impact of social construction on performance forward, more work must be done to understand the selection process for public sector awards, particularly those that are held up as paragons of best practice for departments around the country.

The symbolic politics potentially practiced by both the International Association of Chiefs of Police and the Department of Justice are worthy of discussion here as well. There is no 
reason to doubt that the largest law enforcement body in the country, along with the largest professional association of law enforcement leadership, might want to promote their agendas in the most effective way possible. This could mean forgoing performance measurement as a standard for selecting award nominees and finalists in favor of an approach that rewards the departments they believe will best serve as exemplars of community policing in the public eye. While acting on the impulses of symbolic politics may be a well-intentioned push by an organization to promote certain values, and overreliance on such a strategy, particularly when it comes to promoting a policing intervention, risks promoting ineffective or deleterious practices (Edelman, 1985; Roussell \& Gascon, 2014).

\section{Future Avenues for Research}

As referenced earlier, there are several substantive debates about how community policing is and should be studied, particularly when it comes to measuring performance, the relationship between normatively "good" performance and social equity, and overall viability and utility of community policing as an intervention (McCandless, 2018; Roussell \& Gascon, 2014; Rukus et al., 2018; Willis et al., 2010). This study provides insight into how public recognition and awards fit into this larger debate, and suggests that such accolades, while perhaps useful in other ways, are not likely to improve the performance of an agency that receives them. This finding, in turn, leads to questions about how award finalists and nominees are chosen, the process by which the Department of Justice decides to promote their programs as best practices, and the resulting impact on future award recipients and their performance.

Indeed, the proposition that symbolic politics and social construction play a role in these processes suggests that there are real concerns about social equity in community policing 
practices. Social equity is touted as a pillar of public administration, and the actions of streetlevel bureaucrats, including police, are often noted as an administrative area in which more work is needed to meet this standard (Frederickson, 1990; Svara \& Brunet, 2005). Charbonneau and Riccucci (2008) provide an excellent overview of the literature on social equity in policing with regard to interventions and citizen perceptions, and Dunn (2009) measures racial disparities in traffic ticketing. However, a rigorous review of community policing that considers these elements is long overdue and should focus on whether or not community policing programs are accomplishing their goals, many of which are often tied directly to issues of social equity.

Additionally, scholars must continue reassess crime clearance rates and their utility as a measure of community policing performance. This is tied directly to the research on social equity in policing, as crime clearance rates do not consider wrongful convictions, nor the enormous racial disparities in conviction and sentencing rates across the United States. While crime clearance rates are considered, to this point, a valid measure for performance in community policing, it is worth considering how those rates are calculated and how racial disparities in the justice system may be shaping these and other statistics. Further, the carceral nature of modern policing, particularly as it impacts low-income and minority communities, is unlikely to be shifted simply based on a single intervention such as community policing, and this should also be recognized when measuring performance (Bostaph, 2007; Epp, Maynard-Moody, \& HaiderMarkel, 2014; Soss \& Weaver, 2017).

Finally, future work on community policing must more fully grapple with the idea of race-class-subjugated communities, and the role that policing practices play in shaping and promoting certain interests over others within them (Soss \& Weaver, 2017; Stuart, 2016). Community policing belongs in the larger conversation around the carceral state in criminal 
justice policy, and how communities themselves play important roles in the mitigation or liberation of that state (Beckett \& Murakawa, 2012; Weaver \& Lerman, 2010). This will require more rigorous analysis of race, class, and gender as important variables within the performance of community policing programs, along with the reassessment of traditional performance measures and standards. This work, while difficult, is necessary to move research on performance in policing into the next phase of scholarly discourse.

\section{References}

Abadie, A. (2005). Semiparametric difference-in-differences estimators. The Review of Economic Studies, 72(1), 1-19.

Ammons, D. N., \& Madej, P. M. (2018). Citizen-Assisted Performance Measurement? Reassessing Its Viability and Impact. The American Review of Public Administration, 48(7), 716-729. Retrieved from http://journals.sagepub.com/doi/abs/10.1177/0275074017713295

Austin, P. C. (2009a). The relative ability of different propensity score methods to balance measured covariates between treated and untreated subjects in observational studies. Medical Decision Making, 29(6), 661-677.

Austin, P. C. (2009b). Some methods of propensity - score matching had superior performance to others: results of an empirical investigation and Monte Carlo simulations. Biometrical Journal: Journal of Mathematical Methods in Biosciences, 51(1), 171-184.

Bailey, M. A., \& Rom, M. C. (2004). A wider race? Interstate competition across health and welfare programs. Journal of Politics, 66(2), 326-347. 
Baumgartner, F. R., De Boef, S. L., \& Boydstun, A. E. (2008). The decline of the death penalty and the discovery of innocence: Cambridge University Press.

Beckett, K., \& Murakawa, N. (2012). Mapping the shadow carceral state: Toward an institutionally capacious approach to punishment. Theoretical Criminology, 16(2), 221244.

Bertrand, M., Duflo, E., \& Mullainathan, S. (2004). How much should we trust differences-indifferences estimates? The Quarterly journal of economics, 119(1), 249-275.

Borins, S. (2000). Public service awards programs: an exploratory analysis. Canadian Public Administration, 43(3), 321-342.

Bostaph, L. G. (2007). Race and repeats: The impact of officer performance on racially biased policing. Journal of Criminal Justice, 35(4), 405-417. Retrieved from http://www.sciencedirect.com/science/article/pii/S0047235207000608

Bozeman, B., \& Moulton, S. (2011). Integrative publicness: A framework for public management strategy and performance. Journal of Public Administration Research and Theory, 21(suppl 3), i363-i380.

Braga, A. A. (2005). Hot spots policing and crime prevention: A systematic review of randomized controlled trials. Journal of Experimental Criminology, 1(3), 317-342.

Braga, A. A., \& Bond, B. J. (2008). Policing crime and disorder hot spots: A randomized controlled trial. Criminology, 46(3), 577-607.

Brewster, J., Stoloff, M., \& Sanders, N. (2005). Effectiveness of citizen police academies in training the attitudes, beliefs, and behavior of citizen participants. American Journal of Criminal Justice, 30(1), 21-34. 
Breznau, N. (2016). Positive Returns and Equilibrium: Simultaneous Feedback Between Public Opinion and Social Policy. Policy Studies Journal, 00(00), 1-30.

Bromberg, D. E., Charbonneau, É., \& Smith, A. (2018). Body-Worn Cameras and Policing: A List Experiment of Citizen Overt and True Support. Public Administration Review. doi:10.1111/puar.12924

Campbell, A. L. (2003). How policies make citizens: Senior political activism and the American welfare state: Princeton University Press.

Cann, D., \& Wilhelm, T. (2011). Policy Venues and Policy Change: The Case of Education Finance Reform. Social Science Quarterly, 92(4), 1074-1095.

Carrizales, T. J., Melitski, J., \& Schwester, R. W. (2010). Targeting opportunities for shared police services. Public Performance \& Management Review, 34(2), 251-267. Retrieved from http://www.tandfonline.com/doi/abs/10.2753/PMR1530-9576340206

Caughey, D., \& Warshaw, C. (2016). The Dynamics of State Policy Liberalism, 1936-2014. American Journal of Political Science, 60(4), 899-913.

Chand, D. E. (2019). Is it Population or Personnel? The Effects of Diversity on Immigration Policy Implementation by Sheriff Offices. Public Performance \& Management Review, $1-30$.

Chappell, A. T., MacDonald, J. M., \& Manz, P. W. (2006). The organizational determinants of police arrest decisions. Crime \& Delinquency, 52(2), 287-306. Retrieved from http://cad.sagepub.com/content/52/2/287

Charbonneau, E., \& Riccucci, N. M. (2008). Beyond the usual suspects: An analysis of the performance measurement literature on social equity indicators in policing. Public Performance \& Management Review, 31(4), 604-620. 
Choi, C. G., \& Choi, S. O. (2012). Collaborative partnerships and crime in disorganized communities. Public Administration Review, 72(2), 228-238.

Chun, J. J. (2011). Organizing at the margins: The symbolic politics of labor in South Korea and the United States: Cornell University Press.

Cingranelli, D. L. (1981). Race, politics and elites: Testing alternative models of municipal service distribution. American Journal of Political Science, 25(4), 664-692.

Citrin, J., Reingold, B., Walters, E., \& Green, D. P. (1990). The" official English" movement and the symbolic politics of language in the United States. Western Political Quarterly, 43(3), 535-559.

Cook, P. (1979). The clearance rates as a measure of criminal justice system effectiveness. Journal of Public Economics, 11, 135-142.

Dunn, R. A. (2009). Measuring racial disparities in traffic ticketing within large urban jurisdictions. Public Performance \& Management Review, 32(4), 537-561. Retrieved from http://www.tandfonline.com/doi/abs/10.2753/PMR1530-9576320403

Edelman, M. J. (1985). The Symbolic Uses of Politics: University of Illinois Press.

Engel, R. S., \& Worden, R. E. (2003). Police officers' attitudes, behavior, and supervisory influences: An analysis of problem solving. Criminology, 41(1), 131-166.

Enns, P. K. (2014). The public's increasing punitiveness and its influence on mass incarceration in the United States. American Journal of Political Science, 58(4), 857-872.

Entwistle, T., \& Downe, J. (2005). Picking winners to define and disseminate best practice. Public Policy and Administration, 20(4), 25-37.

Epp, C. R., Maynard-Moody, S., \& Haider-Markel, D. P. (2014). Pulled over: How police stops define race and citizenship: University of Chicago Press. 
Fields, C. (2007). Award Winning Community Policing Strategies: 1996-2006. Department of Justice, Office of Community Oriented Policing Services Retrieved from https://ric-zaiinc.com/Publications/cops-w0451-pub.pdf

Fox, C. J. (1996). Reinventing government as postmodern symbolic politics. Public Administration Review, 56(3), 256.

Frederickson, H. G. (1990). Public administration and social equity. Public Administration Review, 50(2), 228-237.

Frey, B. S. (2007). Awards as compensation. European Management Review, 4(1), 6-14.

Friedmann, R. R. (1992). Community policing: Comparative perspectives and prospects. Basingstoke, UK: Palgrave Macmillan.

Gayles, J. (2007). Race, Reward, and Reform:An Implicative Examination of the Florida School Recognition Program. Educational Policy, 21(3), 439-456. doi:10.1177/0895904806289216

Gerhards, L., \& Siemer, N. (2014). Private versus public feedback: the incentive effects of symbolic awards. Economics Working Papers, 2014 (01), Department of Economics and Business Economics, Aarhus University.

Gorby, D. M. (2013). The Failure of Traditional Measures of Police Performance and the Rise of Broader Measures of Performance. Policing: A Journal of Policy and Practice, 7(4), 392400. Retrieved from http://policing.oxfordjournals.org/content/7/4/392

Greene, J. R., \& Mastrofski, S. D. (1988). Community policing: Rhetoric or reality: Praeger New York.

Guilfoyle, S. (2015). Binary comparisons and police performance measurement: Good or bad? Policing: A Journal of Policy and Practice, 9(2), 195-209. 
Hajage, D., Tubach, F., Steg, P. G., Bhatt, D. L., \& De Rycke, Y. (2016). On the use of propensity scores in case of rare exposure. BMC medical research methodology, 16(1), 38.

Harrits, G. S. (2018). Stereotypes in Context: How and When Do Street-Level Bureaucrats Use Class Stereotypes? Public Administration Review. doi:10.1111/puar.12952

Hartley, J., \& Downe, J. (2007). The shining lights? Public service awards as an approach to service improvement. Public Administration, 85(2), 329-353.

Heinrich, C. J. (2010). A Primer for Applying Propensity-Score Matching. Retrieved from Office of Strategic Planning and Development Effectiveness, Inter-American Development Bank:

Ho, A. T. (2015). Citizen participation in performance measurement. In Democracy and public administration (pp. 119-130): Routledge.

Hvidman, U., \& Andersen, S. C. (2014). Impact of performance management in public and private organizations. Journal of Public Administration Research and Theory, 24(1), 3558.

IACP. (2018a). IACP/Cisco Community Policing Awards. Retrieved from https://www.iacpcommunitypolicing.org/cpa

IACP. (2018b). International Association of Chiefs of Police Membership Criteria. Retrieved from http://www.theiacp.org/Criteria

Imbens, G. W., \& Wooldridge, J. M. (2009). Recent developments in the econometrics of program evaluation. Journal of economic literature, 47(1), 5-86. 
Jeon, Y., \& Haider - Markel, D. P. (2001). Tracing issue definition and policy change: An analysis of disability issue images and policy response. Policy Studies Journal, 29(2), 215-231.

Jordan, A., \& Matt, E. (2014). Designing policies that intentionally stick: policy feedback in a changing climate. Policy Sciences, 47(3), 227-247.

Kapucu, N., Volkov, I., \& Wang, X. (2011). Best practices of best performers: evidence from the Florida Sterling Council Award winners. Public Performance \& Management Review, 34(3), 397-419.

Kosfeld, M., \& Neckermann, S. (2011). Getting more work for nothing? Symbolic awards and worker performance. American Economic Journal: Microeconomics, 3(3), 86-99.

Kouzmin, A., Löffler, E., Klages, H., \& Korac-Kakabadse, N. (1999). Benchmarking and performance measurement in public sectors: towards learning for agency effectiveness. International Journal of Public Sector Management, 12(2), 121-144.

Kreitzer, R. J., \& Watts Smith, C. (2018). Reproducible and Replicable: An Empirical Assessment of the Social Construction of Politically Relevant Target Groups. PS: Political Science \& Politics, 51(4), 768-774.

Langbein, L., \& Stazyk, E. C. (2013). Vive la différence? The impact of diversity on the turnover intention of public employees and performance of public agencies. International Public Management Journal, 16(4), 465-503.

Leon-Moreta, A. (2018). Social Context, Institutional Capacity, and Police Services: A Local Public Economies Perspective. Public Administration Review, 78(2), 270-283. doi:10.1111/puar.12875 
Liederbach, J., Fritsch, E. J., Carter, D. L., \& Bannister, A. (2008). Exploring the limits of collaboration in community policing: A direct comparison of police and citizen views. Policing: An International Journal of Police Strategies \& Management, 31(2), 271-291.

Litwin, K. J. (2004). A multilevel multivariate analysis of factors affecting homicide clearances. Journal of Research in Crime and Delinquency, 41(4), 327-351.

Löffler, E. (2001). Quality awards as a public sector benchmarking concept in OECD member countries: some guidelines for quality award organizers. Public Administration and Development: The International Journal of Management Research and Practice, 21(1), $27-40$.

Mastrofski, S. D., Snipes, J. B., Parks, R. B., \& Maxwell, C. D. (2000). The helping hand of the law: police control of citizens on request. Criminology, 38(2), 307-342.

McCandless, S. (2018). Improving Community Relations: How Police Strategies to Improve Accountability for Social Equity Affect Citizen Perceptions. Public Integrity, 20(4), 370385.

Meier, K. J., Mastracci, S. H., \& Wilson, K. (2006). Gender and emotional labor in public organizations: An empirical examination of the link to performance. Public Administration Review, 66(6), 899-909.

Meier, K. J., Rutherford, A., \& Avellaneda, C. N. (2017). Comparative public management: Why national, environmental, and organizational context matters: Georgetown University Press.

Mettler, S., \& SoRelle, M. (2014). Policy feedback theory. In P. A. Sabatier (Ed.), Theories of the Policy Process (3 ed.). Boulder, CO: Westview Press. 
Mettler, S., \& Soss, J. (2004). The consequences of public policy for democratic citizenship: Bridging policy studies and mass politics. Perspectives on Politics, 2(1), 55-73.

Moore, M. H. (1994). Research synthesis and policy implications. In D. P. Rosenbaum (Ed.), The challenge of community policing: Testing the promises. Thousand Oaks, CA: Sage Publications.

Moynihan, D. P. (2008). The dynamics of performance management: Constructing information and reform: Georgetown University Press.

Moynihan, D. P. (2015). Uncovering the circumstances of performance information use findings from an experiment. Public Performance \& Management Review, 39(1), 33-57.

Nagin, D. S., Solow, R. M., \& Lum, C. (2015). Deterrence, criminal opportunities, and police. Criminology, 53(1), 74-100.

Nelligan, P. J., \& Bourns, W. (2011). Municipal Contracting With County Sheriffs for Police Services in California: Comparison of Cost and Effectiveness. Police Quarterly, 14(1), 70-95.

Nicholson-Crotty, J., Nicholson-Crotty, S., \& Li, D. (2018). Recruit Screening, Representation, and the Moral Hazard Problem in Policing. Public Performance \& Management Review, $1-21$.

Nicholson-Crotty, J., \& Nicholson - Crotty, S. (2004). Social construction and policy implementation: Inmate health as a public health issue. Social Science Quarterly, 85(2), $240-256$.

Nicholson-Crotty, S., Peterson, D. A. M., \& Ramirez, M. D. (2009). Dynamic representation(s): Federal criminal justice policy and an alternative dimension of public mood. Political Behavior, 31(4), 629-655. 
O’Neill, S., Kreif, N., Grieve, R., Sutton, M., \& Sekhon, J. S. (2016). Estimating causal effects: considering three alternatives to difference-in-differences estimation. Health Services and Outcomes Research Methodology, 16(1-2), 1-21.

O’Toole, L. J., \& Meier, K. J. (2014). Public management, context, and performance: In quest of a more general theory. Journal of Public Administration Research and Theory, 25(1), $237-256$.

Oberfield, Z. W. (2011). Socialization and self-selection: how police officers develop their views about using force. Administration \& Society, 44(6), 702-730.

Ospina, S., Cunill Grau, N., \& Zaltsman, A. (2004). Performance evaluation, public management improvement and democratic accountability: Some lessons from Latin America. Public Management Review, 6(2), 229-251.

Ostrom, E., \& Whitaker, G. (1974). Community control and governmental responsivness: The case of police in black neighborhoods. (R74-2). Washington, D.C.: National Criminal Justice Reference Service

Owens, M. L., \& Smith, A. R. (2012). “Deviants” and democracy: Punitive policy designs and the social rights of felons as citizens. American Politics Research, 40(3), 531-567.

Pasha, O. (2018). Can Performance Management Best Practices Help Reduce Crime? Public Administration Review, 78(2), 217-227. doi:10.1111/puar.12856

Percival, G. L. (2009). Testing the impact of racial attitudes and racial diversity on prisoner reentry policies in the US states. State Politics \& Policy Quarterly, 9(2), 176-203.

Pogarsky, G., \& Loughran, T. A. (2016). The policy-to-perceptions link in deterrence: Time to retire the clearance rate. Criminology \& Pub. Pol'y, 15, 777. 
Pollack, H. A. (2017). Efficacy Is More Effective Than It Seems. Criminology \& Public Policy, $16(3), 815-820$.

Prokos, A., \& Padavic, I. (2002). 'There oughtta be a law against bitches': masculinity lessons in police academy training. Gender Work and Organization(9), 439-459.

Rangarajan, N. (2008). Evidence of different types of creativity in government: a multimethod assessment. Public Performance \& Management Review, 32(1), 132-163.

Roberts, A. (2008). The influences of incident and contextual characteristics on crime clearance of nonlethal violence: A multilevel event history analysis. Journal of Criminal Justice, $36(1), 61-71$.

Rosenblatt, M. (2011). The use of innovation awards in the public sector: Individual and organizational perspectives. Innovation, 13(2), 207-219.

Roussell, A., \& Gascon, L. (2014). Defining 'Policeability': Cooperation, Control, and Resistance in South Los Angeles Community-Police Meetings. Social Problems, 61(2), 237-258.

Rukus, J., Warner, M. E., \& Zhang, X. (2018). Community policing: Least effective where need is greatest. Crime \& Delinquency, 64(14), 1858-1881.

Saunders, J., Robbins, M., \& Ober, A. J. (2017). Moving From Efficacy to Effectiveness. Criminology \& Public Policy, 16(3), 787-814.

Scheingold, S. A. (1974). The Myth of Rights. New Haven: Yale University Press.

Schneider, A., Ingram, H., \& de Leon, P. (2014). Democratic policy design: Social construction of target populations. In P. A. Sabatier (Ed.), Theories of the Policy Process (3 ed.). Boulder, CO: Westview Press.

Sears, D. O., Hensler, C. P., \& Speer, L. K. (1979). Whites' opposition to "busing”: Self-interest or symbolic politics? American Political Science Review, 73(2), 369-384. 
Shane, J. M. (2010). Organizational stressors and police performance. Journal of Criminal Justice, 38(4), 807-818.

Sharp, E. B. (2014). Minority representation and order maintenance policing: toward a contingent view. Social Science Quarterly, 95(4), 1155-1171.

Skogan, W. G. (2004). Community policing: Can it work? : Wadsworth/Thomson Learning Belmont.

Skolnick, J. H., \& Bayley, D. H. (1988). Theme and variation in community policing. Crime and justice, 10, 1-37.

Soss, J. (1999). Lessons of welfare: Policy design, political learning, and political action. American Political Science Review, 93(02), 363-380.

Soss, J., Fording, R. C., \& Schram, S. (2011). Disciplining the poor: Neoliberal paternalism and the persistent power of race: University of Chicago Press.

Soss, J., Fording, R. C., \& Schram, S. F. (2008). The color of devolution: Race, federalism, and the politics of social control. American Journal of Political Science, 52(3), 536-553.

Soss, J., \& Schram, S. F. (2007). A public transformed? Welfare reform as policy feedback. American Political Science Review, 101(01), 111-127.

Soss, J., \& Weaver, V. (2017). Police Are Our Government: Politics, Political Science, and the Policing of Race-Class Subjugated Communities. Annual Review of Political Science, $20,565-591$.

Span, K. C., Luijkx, K. G., Schols, J. M., \& Schalk, R. (2011). The relationship between governance roles and performance in local public interorganizational networks: A conceptual analysis. The American Review of Public Administration, 42(2), 186-201. 
Steinacker, A. (2006). Externalities, prospect theory, and social construction: when will government act, what will government do? Social Science Quarterly, 87(3), 459-476.

Stuart, F. (2016). Down, out, and under arrest: Policing and everyday life in Skid Row: University of Chicago Press.

Svara, J. H., \& Brunet, J. R. (2005). Social equity is a pillar of public administration. Journal of Public Affairs Education, 253-258.

Swindell, D., \& Kelly, J. M. (2000). Linking citizen satisfaction data to performance measures: A preliminary evaluation. Public Performance \& Management Review, 30-52.

Taylor, B., Koper, C. S., \& Woods, D. J. (2011). A randomized controlled trial of different policing strategies at hot spots of violent crime. Journal of Experimental Criminology, $7(2), 149-181$.

Taylor, R. B., \& Lawton, B. A. (2012). An Integrated Contextual Model of Confidence in Local Police. Police Quarterly, 15(4), 414-445. doi:10.1177/1098611112453718

van Gelderen, B. R., \& Bik, L. W. (2016). Affective organizational commitment, work engagement and service performance among police officers. Policing: An International Journal of Police Strategies \& Management, 39(1), 206-221.

Wang, X. (2002). Assessing performance measurement impact: A study of US local governments. Public Performance \& Management Review, 26(1), 26-43.

Watkins-Hayes, C. (2009). The new welfare bureaucrats: Entanglements of race, class, and policy reform: University of Chicago Press.

Weaver, V. M., \& Lerman, A. E. (2010). Political consequences of the carceral state. American Political Science Review, 104(04), 817-833. 
Weisburd, D., \& Braga, A. A. (2006). Police innovation: Contrasting perspectives: Cambridge University Press.

Willis, J. J., Mastrofski, S. D., \& Kochel, T. R. (2010). The co-implementation of Compstat and community policing. Journal of Criminal Justice, 38(5), 969-980.

Wilson, J. M. (2006). Community policing in America: Taylor \& Francis.

Zeemering, E. S. (2018). Why Terminate? Exploring the End of Interlocal Contracts for Police Service in California Cities. The American Review of Public Administration, 48(6), 596609. Retrieved from http://journals.sagepub.com/doi/abs/10.1177/0275074017701224

Zhao, J., Scheider, M. C., \& Thurman, Q. (2002). Funding community policing to reduce crime: Have COPS grants made a difference? Criminology \& Public Policy, 2(1), 7-32.

Zimring, F. E. (2011). The city that became safe: New York's lessons for urban crime and its control: Oxford University Press. 
Table 1: Defining Elements of a Community Policing Program

Function

Order maintenance, problem solving, developing partnerships with communities.

Organizational Design

Pushing decisions to the street-level, creating neighborhood stations, decentralizing

Relationship to

Permanent beat assignments, regular meetings,

Environment assigned caseloads

Demand

Relying on citizen feedback, treating citizens as consumers of a service

Tactics

Foot patrols, counseling, community meetings

Outcomes

Satisfaction, crime control, quality of life

Adapted from Greene \& Mastrofski, 1988 
Table 2: Variables

Year

County

Violent Crimes

Property Crimes

Felony Arrests

Misdemeanor Arrests

Proportion of

Population (Black)

Proportion of

Population (Hispanic)

Proportion of

Population (API)

Proportion of

Population (Other)

Population Served

Violent Crime

Clearance Rate

Property Crime

Clearance Rate
The year in which an observation was recorded.

The county in which a given department is located.

The number of violent crimes committed in a given year within the jurisdiction of a given department.

The number of crimes against property committed in a given year within the jurisdiction of a given department.

The number of felony arrests in a given year within the jurisdiction of a given department.

The number of misdemeanor arrests in a given year within the jurisdiction of a given department.

The percentage of self-identified Black citizens within the jurisdiction of a given department in a given year.

The percentage of self-identified Hispanic citizens within the jurisdiction of a given department in a given year.

The percentage of self-identified Asian/Pacific Islander citizens within the jurisdiction of a given department in a given year.

The percentage of citizens who self-identity their race as "other" within the jurisdiction of a given department in a given year.

The total number of citizens served by a given department in a given year.

Rate of violent crimes cleared by a given department in a given year. A cleared offense is when at least one person involved has been arrested and charged.

Rate of property crimes cleared by a given department in a given year. A cleared offense is when at least one person involved has been arrested and charged. 
Table 3: Propensity Score Matching

Model 1

Violent Crime

Clearance Rate

Treated

\section{Constants}

2.19

(2.0860)

$50.87 * * *$

$(0.3502)$
Model 2

Property Crime

Clearance Rate

$-4.23 * * *$

(1.2411)

$16.96 * * *$

(0.2084)

$\mathrm{N}=3193.00$

$\mathrm{F}=1.11$

Pseudo $\mathrm{r} 2=0.1428$

(Standard errors in parentheses)

$* * \mathrm{p}<.05, * * * \mathrm{p}<.01$

\section{Fig. 1: Propensity Score Distributions Before and After Nearest-Neighbor Matching}
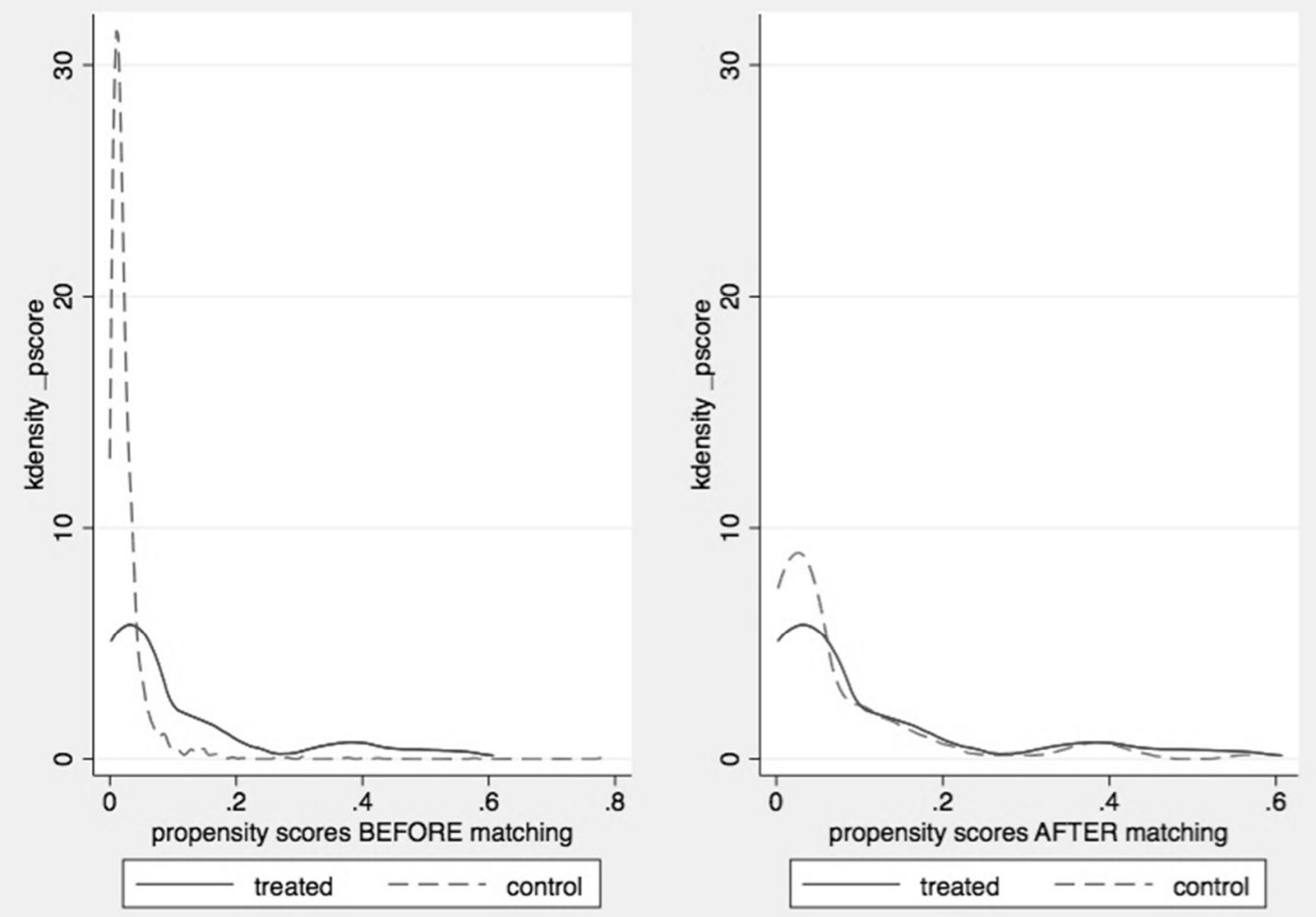